\title{
Analisis Aplikasi Integrated Postal Operations System (IPOS) Pada PT. Pos Indonesia (Persero) KPRK Jombang Menggunakan Metode PIECES
}

\author{
Ayu Adelina Suyono ${ }^{1}$, Ulfiatin Nur Indianiati ${ }^{2}$, Enes Maulia Rizki ${ }^{3}$, Siti Hamidah ${ }^{4}$, Erliyah Nurul Jannah ${ }^{5}$ \\ Sistem Informasi Fakultas Teknik Universitas Pesantren Tinggi Darul ‘Ulum (Unipdu) Jombang \\ E-mail: 1'aadelinasuyono@gmail.com, ${ }^{2}$ ulfiatin.19@gmail.com, ${ }^{3}$ enesmauliarizki@ gmail.com \\ ${ }^{4}$ hamidahsiti007@gmail.com, ${ }^{5}$ erliyah.nj@ft.unipdu.ac.id
}

\begin{abstract}
Abstrak
PT. Pos Indonesia (Persero) Kantor Pemeriksa (KPRK) Jombang atau Kantor Pos Jombang merupakan Badan Usaha Milik Negara (BUMN) yang bergerak dalam bidang jasa pengiriman. Dalam proses bisnisnya, Kantor Pos Jombang menggunakan sebuah aplikasi bernama Integrated Postal Operations System (IPOS). Dalam artikel ini, penulis melakukan analisis pada Aplikasi IPOS untuk mengetahui penerapannya pada transaksi pengiriman surat dan barang di Loket Retail Kantor Pos Jombang dan mengetahui aspek PIECES (Performance, Information/Data, Economic, Control/Security, Efficiency, dan Service) dari Aplikasi IPOS. Metode pengumpulan data yang digunakan penulis adalah wawancara, observasi, dan studi pustaka. Dari hasil analisis yang telah dilakukan, dapat disimpulkan bahwa Aplikasi IPOS sangat mendukung Kantor Pos Jombang dalam transaksi pengiriman surat dan barang. Aplikasi IPOS dapat mempercepat dan mempermudah proses transaksi pengiriman, serta dapat memberikan informasi yang akurat, tepat waktu, dan relevan.
\end{abstract}

Kata kunci: Proses Transaksi Pengiriman, Aplikasi IPOS, Metode PIECES.

\section{Abstract}

PT. Pos Indonesia (Persero) Kantor Pemeriksa (KPRK) Jombang or Jombang Post Office was the State Owned Enterprises (SOEs) which is engaged in delivery services. In its business processes, Jombang Post Office uses an application called Integrated Postal Operations System (IPOS). In this paper, authors analyzed IPOS to observe the PIECES (Performance, Information/Data, Economic, Control/Security, Efficiency, and Service) aspects of IPOS in the task of mail and goods delivery transaction in Retail Locket of Post Office Jombang. The, data collection methods used by the author are interview, observation, and literature study. From the analysis that has been done, it can be concluded that IPOS strongly supports Jombang Post Office in transaction of mail and goods delivery. IPOS can speed up and simplify the transaction of mail and goods delivery, and it can provide information that is accurate, timely, and relevant.

Key word: Transaction of Mail and Goods Delivery, IPOS, PIECES Methods.

\section{Pendahuluan}

PT. Pos Indonesia (Persero) Kantor Pemeriksa (KPRK) Jombang atau Kantor Pos Jombang merupakan Badan Usaha Milik Negara (BUMN) yang bergerak dalam bidang jasa. Kantor Pos Jombang Jombang berlokasi di Jl. KH. Wahid Hasyim No. 184. Sebagai penyedia jasa pengiriman, Kantor Pos Jombang membutuhkan sebuah sistem agar surat dan barang yang dikirim dapat tepat sesuai dengan tujuan pengiriman. Kantor Pos Jombang telah memiliki aplikasi yang digunakan untuk proses transaksi pengiriman surat dan barang. Aplikasi pengiriman surat dan barang ini disebut dengan Aplikasi Integrated Postal Operations System (IPOS).

Aplikasi IPOS dibangun dengan berbasis web. Aplikasi IPOS terintegrasi langsung dengan database server pusat yang berlokasi di Bandung dan seluruh cabang POS di Indonesia. Penggunaan database server yang terpusat bertujuan untuk memberikan informasi yang cepat, akurat, dan relevan, sehingga informasi yang disajikan tidak basi (Djahir, 2015).

Aplikasi IPOS merupakan Sistem Informasi Manajemen (SIM) yang digunakan untuk proses transaksi pengiriman surat dan barang. SIM merupakan sistem informasi yang berguna untuk menyajikan data yang digunakan untuk mendukung operasi, manajemen, dan pengambilan keputusan dalam suatu organisasi (Kadir, 2014). Selain itu, SIM juga berfungsi dalam melakukan pengolahan 
transaksi yang sangat berguna untuk kepentingan organisasi (Gaol, 2008). Aplikasi IPOS dapat mendukung operasi Kantor Pos Jombang dalam proses transaksi pengiriman surat dan barang. Aplikasi IPOS juga digunakan untuk mengatur sumber daya yang terdapat di Kantor Pos Jombang, misalnya penggunaan Aplikasi IPOS yang disesuaikan dengan level pengguna sesuai dengan kebutuhan para pengguna-pengguna tersebut.

Selain itu, Aplikasi IPOS juga dapat memberikan informasi yang akurat kepada para pengguna, misalnya kepada Supervisor. Telah kita ketahui bahwa informasi mempunyai manfaat dan mempunyai peranan yang sangat dominan dalam suatu organisasi/perusahaan (Gaol, 2008). Dengan memanfaatkan Aplikasi IPOS Supervisor dapat mengawasi segala aktivitas transaksi yang dilakukan oleh Loket Retail, sehingga mempermudah Supervisor untuk mengambil keputusan.

Dalam artikel ini, penulis melakukan analisis pada Aplikasi IPOS. Analisis Aplikasi IPOS bertujuan untuk mengidentifikasi penerapan Aplikasi IPOS pada proses transaksi pengiriman surat dan barang di Kantor Pos Jombang. Terdapat beberapa aspek yang dianalisis dalam artikel ini, aspek-aspek tersebut adalah PIECES (Performance, Information/Data, Economic, Control/Security, Efficiency, dan Service). Analisis PIECES digunakan untuk mengidentifikasi kelemahan sistem yang menjadi rekomendasi untuk perbaikan-perbaikan yang harus dibuat pada sistem yang akan dikembangkan (Fatta, 2007). Oleh sebab itu, penulis menerapkan metode ini dengan tujuan untuk mengidentifikasi kelemahan pada Aplikasi IPOS, sehingga nantinya dapat dihasilkan rekomendasi-rekomendasi untuk perbaikan aplikasi. Dengan adanya rekomendasi tersebut, diharapkan dapat membuat penerapan aplikasi IPOS menjadi lebih baik dari saat ini.

\section{Metode Penelitian}

Metode analisis yang digunakan penulis untuk menganalisis Aplikasi IPOS adalah metode PIECES. Metode PIECES digunakan untuk mengevaluasi bermacam-macam prosedur operasional dalam sebuah organisasi, perusahaan, institusi terkait, maupun lembaga pemerintahan. Terdapat beberapa penelitian yang terkait dengan penggunaan Metode PIECES. Diantaranya adalah Evaluasi Penerapan Sistem Informasi pada Politeknik LP3I Jakarta dengan Metode PIECES (Tullah, 2014). Selanjutnya Evaluasi Implementasi Sistem Electronic Health Record (EHR) di Rumah Sakit Akademik Universitas Gadjah Mada Berdasarkan Metode PIECES (Nuryati, 2015).

Tabel 1 Penelitian Terkait Metode PIECES

\begin{tabular}{|c|c|c|c|c|}
\hline No. & $\begin{array}{c}\text { Nama Peneliti dan } \\
\text { Tahun }\end{array}$ & Masalah & Metode & Hasil \\
\hline 1) & Tullah, 2014 & $\begin{array}{l}\text { Rata-rata pengguna } \\
\text { mengeluhkan lambatnya } \\
\text { proses (loading) dari sistem } \\
\text { informasi, sehingga } \\
\text { mengakibatkan tidak } \\
\text { efektifnya waktu dalam } \\
\text { penggunaan sistem informasi }\end{array}$ & PIECES & $\begin{array}{l}\text { Rata-rata pengguna } \\
\text { merasa, sistem informasi } \\
\text { pada Politeknik LP31 } \\
\text { Jakarta masih kurang } \\
\text { memenuhi harapan } \\
\text { mereka sebesar 14,5\% }\end{array}$ \\
\hline 2) & Nuryati, 2015 & $\begin{array}{l}\text { Melakukan evaluasi sistem } \\
\text { EHR di RS Akademik UGM } \\
\text { untuk mengetahui keinginan } \\
\text { dan pendapat pengguna } \\
\text { terhadap aspek-aspek yang } \\
\text { mempengaruhi sistem HER } \\
\text { agar RS Akademik UGM } \\
\text { dapat mengetahui dan lebih } \\
\text { memahami hambatan- } \\
\text { hambatan maupun } \\
\text { keuntungan dari penggunaan } \\
\text { sistem yang selama ini } \\
\text { berjalan }\end{array}$ & PIECES & $\begin{array}{l}\text { Tingkat aspek PIECES } \\
\text { sistem EHR di RS } \\
\text { AkademiK UGM adalah } \\
\text { baik dengan sebagian } \\
\text { besar responden } \\
\text { memberikan jawaban baik } \\
\text { sebesar 59,82\% }\end{array}$ \\
\hline
\end{tabular}


Metode PIECES digunakan untuk mengidentifikasi kelemahan sistem yang menjadi rekomendasi untuk perbaikan-perbaikan yang harus dibuat pada sistem yang akan dikembangkan (Fatta, 2007). Hasil analisis dari metode PIECES biasanya berupa pernyataan-pernyataan rekomendasi. PIECES adalah metode yang menggunakan enam variabel yaitu Performance, Information/Data, Economic, Control/Security, Efficiency, dan Service (Fatta, 2007).

a) Performance (Analisis Kinerja)

Aspek Performance digunakan untuk mengukur kinerja dalam suatu proses bisnis. Masalah kinerja terjadi ketika tugas-tugas bisnis yang dijalankan tidak mencapai sasaran. Kinerja diukur dengan jumlah produksi dan waktu tanggap. Jumlah produksi adalah jumlah pekerjaan yang bisa diselesaikan selama jangka waktu tertentu. Waktu tanggap adalah keterlambatan rata-rata antara suatu transaksi dengan tanggapan yang diberikan kepada transaksi tersebut.

b) Information (Analisis Informasi)

Informasi merupakan komoditas krusial bagi pengguna akhir. Evaluasi terhadap kemampuan sistem informasi dalam menghasilkan informasi yang bermanfaat perlu dilakukan untuk menyikapi peluang dan menangani masalah yang muncul. Dalam hal ini meningkatkan kualitas informasi tidak dengan menambah jumlah informasi, karena terlalu banyak informasi malah akan menimbulkan masalah baru.

c) Economic (Analisis Ekonomi)

Alasan ekonomi merupakan motivasi paling umum bagi suatu proyek. Pijakan bagi kebanyakan manajer adalah biaya atau rupiah. Persoalan ekonomis dan peluang berkaitan dengan masalah biaya. Adapun hal-hal yang harus diperhatikan dapat disimak berikut:

1) Biaya

- Biaya tidak diketahui

- Biaya tidak dapat dilacak ke sumber

- Biaya terlalu tinggi

2) Keuntungan

- Pasar-pasar baru dapat dieskplorasi

- Pemasaran saat ini dapat diperbaiki

- Pesanan-pesanan dapat ditingkatkan

d) Control/Security (Analisis Keamanan)

Kontrol dipasang untuk meningkatkan kinerja sistem, mencegah, atau mendeteksi kesalahan sistem, menjamin keamanan data, dan persyaratan.

e) Efficiency (Analisis Efisiensi)

Efisiensi menyangkut bagaimana menghasilkan output sebanyak-banyaknya dengan input yang sekecil mungkin.

f) Services (Analisis Layanan)

Berikut adalah keriteria penilaian dimana kualitas suatu sistem bisa dikatakan buruk:

1) Sistem menghasilkan produk yang tidak akurat

2) Sistem menghasilkan produk yang tidak konsisten

3) Sistem menghasilkan produk yang tidak dipercaya

4) Sistem tidak mudah dipelajari

5) Sistem tidak mudah digunakan

6) Sistem canggung untuk digunakan

7) Sistem tidak fleksibel

Metode pengumpulan data yang digunakan penulis adalah wawancara, observasi, dan studi pustaka. Metode wawancara dilakukan di Kantor Pos Jombang dengan narasumber beberapa karyawan yang bertugas di Loket Retail. Metode observasi dilakukan oleh penulis di Kantor Pos Jombang selama satu bulan, terhitung mulai tanggal 28 Juli 2015-31 Agustus 2015. Metode studi pustaka dilakukan untuk mencari sumber-sumber literatur yang menyajikan data sesuai dengan permasalahan yang dihadapi.

\section{Hasil dan Pembahasan}

Pembahasan dari penerapan aplikasi IPOS pada Loket Retail Kantor Pos Jombang meliputi penjelasan alur proses pencatatan transaksi pengiriman surat dan barang menggunakan IPOS. Dari 
penjelasan proses tersebut, kemudian dilakukan analisis yang hasilnya disajikan pada bagian Hasil Analisis Aplikasi IPOS Menggunakan Metode PIECES.

\subsection{Proses Transaksi Pengiriman Surat dan Barang}

Aplikasi IPOS adalah sebuah aplikasi berbasis web yang digunakan untuk proses transaksi pengiriman surat dan barang. Aplikasi IPOS memiliki dua kegunaan utama, yaitu: Mempermudah proses transaksi pengiriman surat dan barang baik di dalam maupun luar maupun luar negeri serta Membuat laporan harian transaksi pengiriman surat dan barang. Pada Aplikasi IPOS terdapat beberapa menu. Dalam menu All Programs terdapat beberapa submenu, antara lain:

1) Administrasi Transaksi

Menu Administrasi Transaksi digunakan Petugas Loket untuk melakukan Buka Backsheet pada pembukaan Loket, Tutup Backsheet pada penutupan Loket, melihat Referensi Kodepos dan Tarif, serta Cek Kurs:

a) Buka Backsheet

Menu Buka Backsheet digunakan oleh Petugas Loket untuk melakukan buka backsheet pada pembukaan Loket.

b) Tutup Backsheet

Menu Tutup Backsheet digunakan oleh Petugas Loket untuk melakukan tutup backsheet pada penutupan Loket.

c) Referensi Kode Pos dan Tarif

Menu Referensi Kode Pos dan Tarif digunakan untuk melihat kode pos dan daftar harga untuk pengiriman surat dan barang.

d) Cek Kurs

Menu Cek Kurs digunakan untuk mengetahui tentang informasi kurs terkini.

2) Kiriman Pos

Menu Kiriman Pos digunakan Petugas Loket untuk melakukan proses transaksi Loket Kiriman Pos, Backsheet Kiriman Pos, Loket Kiriman Korporat, Loket Korporat by File:

a) Loket Kiriman Pos

Menu Loket Kiriman Pos digunakan untuk melakukan transaksi pengiriman surat dan barang.

b) Backsheet Kiriman Pos

Menu Backsheet Kiriman Pos berfungsi untuk melihat dan mencetak Backsheet pada hari sesuai tanggal hari ini. Backsheet digunakan sebagai laporan harian yang mencatat data transaksi pada hari ini.

c) Loket Kiriman Korporat

Menu Loket Kiriman Korporat digunakan untuk perusahaan atau instansi yang berlangganan dalam melakukan pengiriman surat atau barang, akan tetapi pembayaran dilakukan secara kredit atau satu bulan sekali. Dalam pembayaran ini dapat dilakukan di kantor pos pusat maupun cabang.

d) Loket Korporat by File

Menu Loket Korporat by File digunakan untuk perusahaan atau instansi berlangganan dan sudah memiliki file tersendiri sehingga tidak perlu memasukkan data pelanggan secara manual.

3) Tes Printer

Menu Tes Printer digunakan untuk menyambungkan aplikasi dengan mesin printer. Jika Petugas

Loket tidak atau belum Tes Printer maka mesin printer tidak akan dapat mencetak secara otomatis.

Aplikasi IPOS di Kantor Pos Jombang memiliki tiga level pengguna, antara lain: Admin, Supervisor, dan Loket Retail. Admin adalah pengguna yang bertugas untuk mendaftarkan level Supervisor sehingga Supervisor dapat online ke dalam aplikasi. Supervisor merupakan level pengguna yang bertugas untuk mendaftarkan Loket Retail yang berada di bawahnya sehingga dapat online ke dalam aplikasi. Selain itu, Supervisor juga bertugas untuk mengawasi kinerja yang dilakukan oleh Loket Retail. Loket Retail adalah level pengguna yang bertugas untuk proses transaksi pengiriman surat dan barang. Proses ini meliputi proses pencatatan transaksi dan proses pencetakan laporan transaksi. Pada makalah ini akan dibahas penggunaan Aplikasi IPOS untuk transaksi pengiriman surat dan barang dengan level pengguna Loket Retail.

Register: Jurnal Ilmiah Teknologi Sistem Informasi, Januari 2016, Volume 2, Nomor 1 | 25 
Cara Kerja Aplikasi Integrated Postal Operations System (IPOS) untuk Proses Transaksi Pengiriman Surat dan Barang Loket Retail dapat dijelaskan seperti langkah-langkah berikut:

1) Petugas Loket harus login terlebih dahulu dengan memasukkan username dan password, seperti pada Gambar 1.

2) Jika login berhasil, maka Petugas Loket dapat masuk ke Halaman Utama Aplikasi IPOS seperti pada Gambar 2.

3) Untuk membuka Loket, Petugas terlebih dahulu harus membuka backsheet. Petugas Loket memilih menu Start - All Programs - Administrasi Transaksi - Buka Backsheet. Menu buka Backsheet dapat dilihat pada Gambar 3.

4) Pilih Buka Backsheet, maka akan tampil informasi seperti pada Gambar 4.

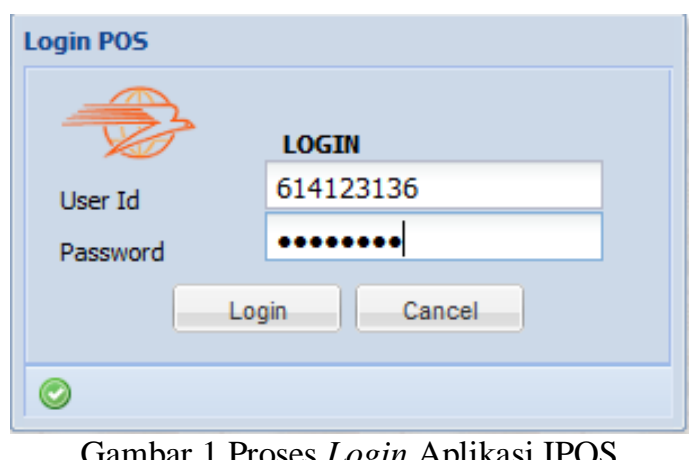

5) Pilih Buka, maka akan tampil informasi seperti pada Gambar 5.

6) Pilih Yes, maka akan tampil informasi seperti pada Gambar 6.

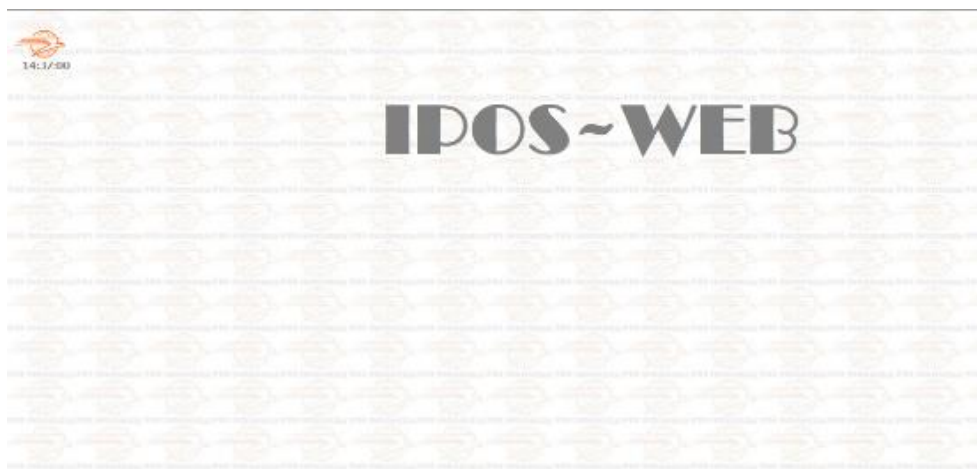

Gambar 2 Halaman Utama Aplikasi IPOS

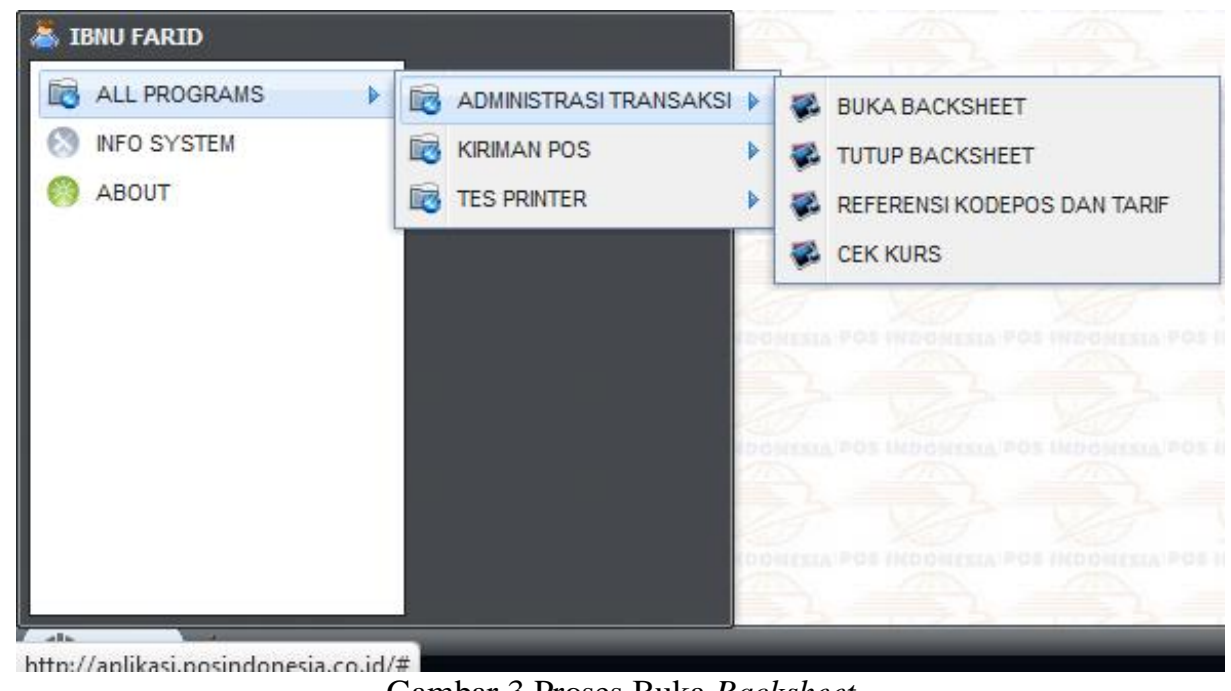

Gambar 3 Proses Buka Backsheet

26 | Register: Jurnal Ilmiah Teknologi Sistem Informasi, Januari 2016, Volume 2, Nomor 1 


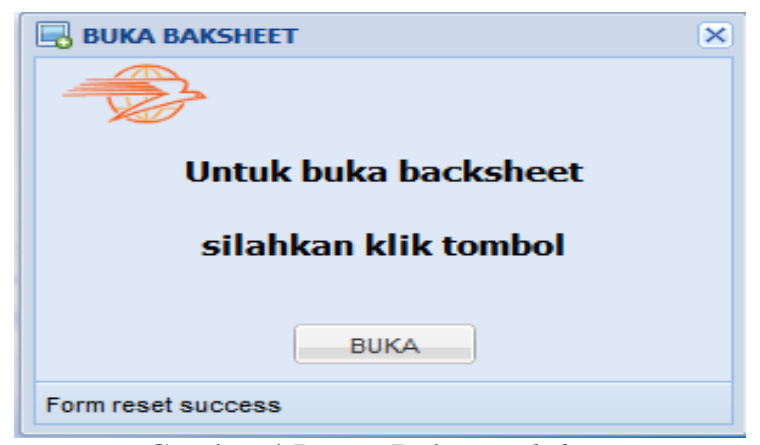

Gambar 4 Proses Buka Backsheet

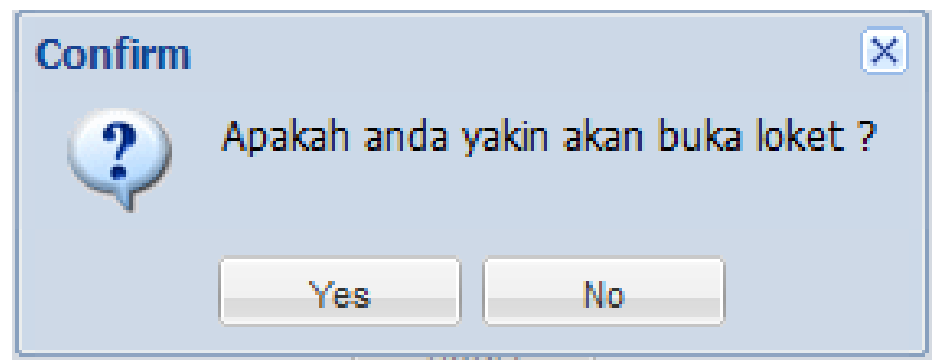

Gambar 5 Proses Buka Backsheet

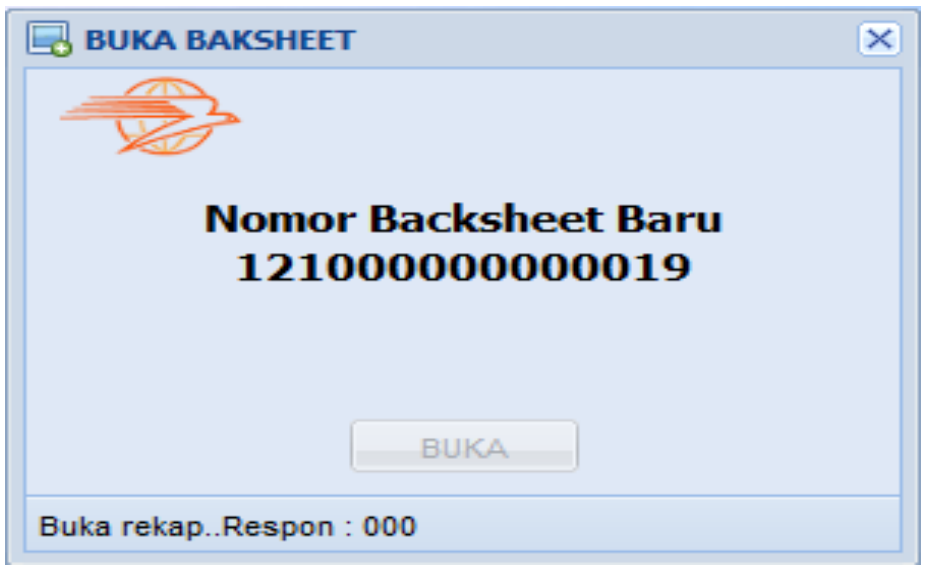

Gambar 6 Proses Buka Backsheet

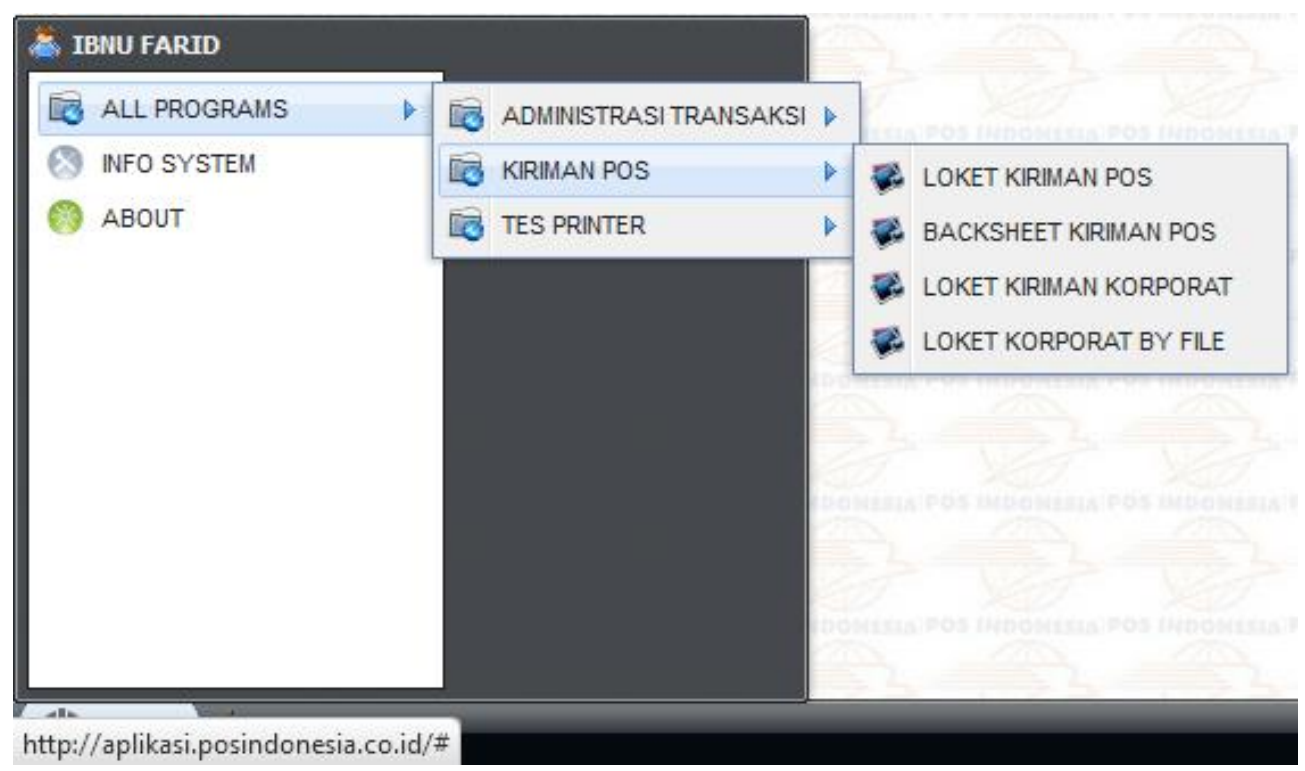

Gambar 7 Proses Transaksi Pengiriman 


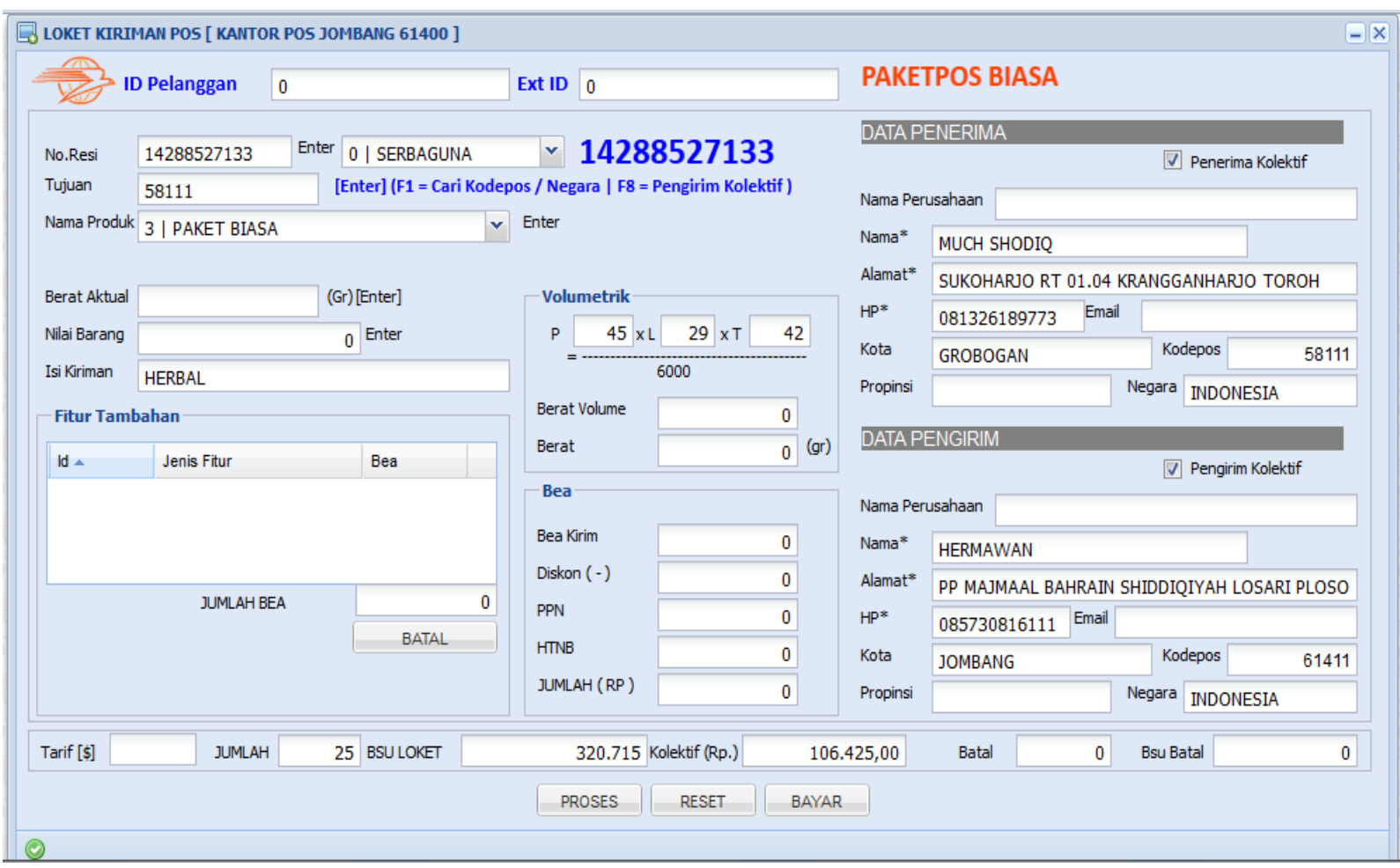

\section{Gambar 8 Proses Transaksi Pengiriman}

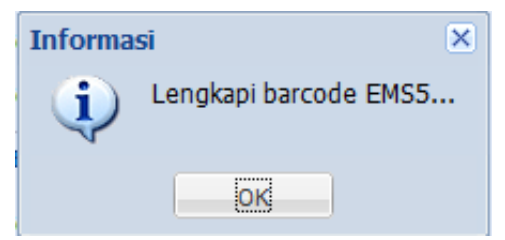

Gambar 9 Proses Transaksi Pengiriman

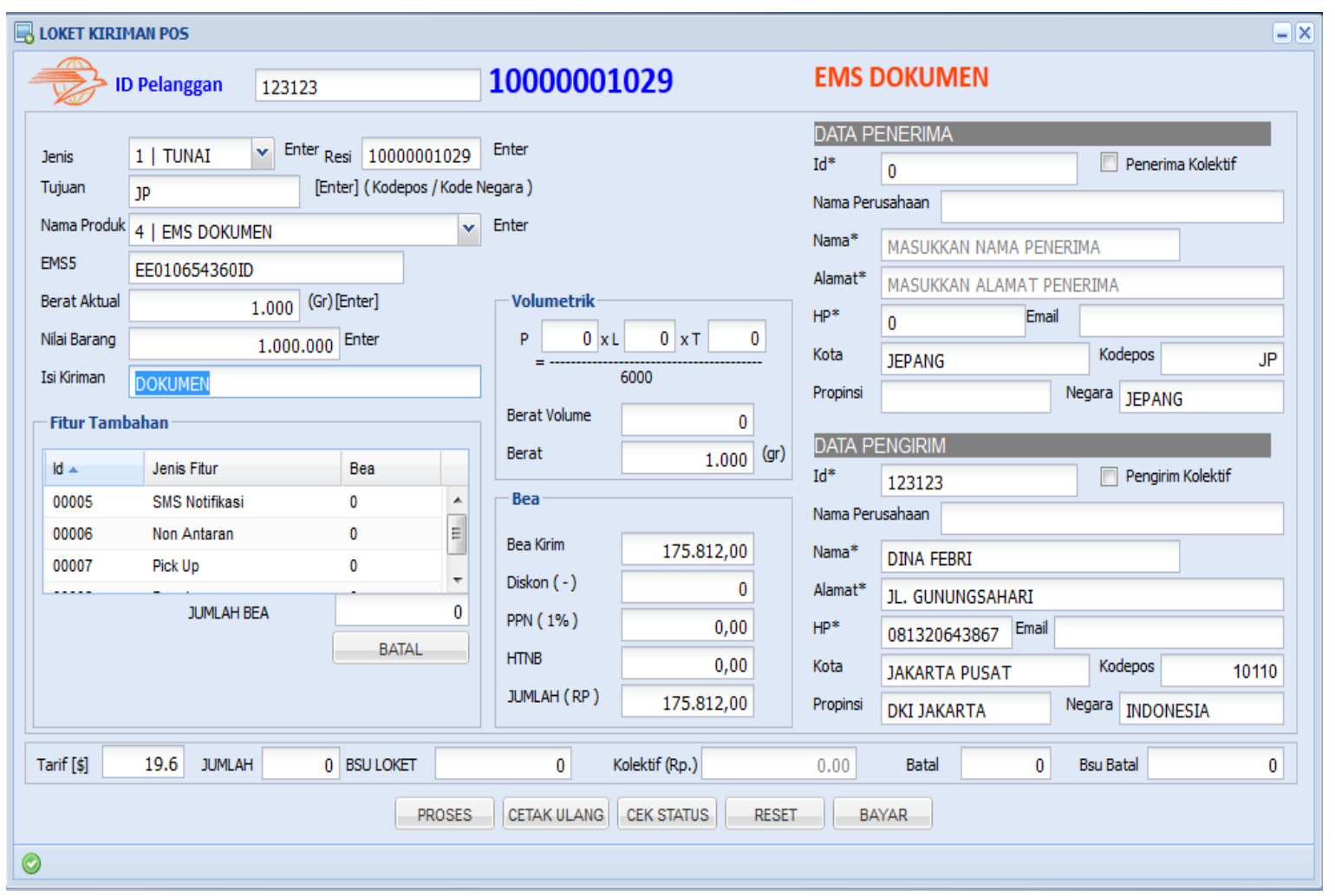

\section{Gambar 10 Proses Transaksi Pengiriman}

28 | Register: Jurnal Ilmiah Teknologi Sistem Informasi, Januari 2016, Volume 2, Nomor 1

http://www.journal.unipdu.ac.id/index.php/register/article/view/442 
7) Untuk melakukan transaksi pengiriman surat dan barang, Petugas Loket memilih menu Start - All Programs - Kiriman Pos - Loket Kiriman Pos sehingga tampil layar seperti pada Gambar 7.

8) Setelah memilih menu Loket Kiriman Pos, maka akan tampil seperti pada Gambar 8.

9) Masukan ID Pelanggan. Apabila pelanggan mempunyai ID Pelanggan, data pelanggan akan terisi secara otomatis, tekan ENTER.

10) Masukan No Resi, tekan ENTER.

11) Masukan Tujuan, isikan dengan Kode Pos atau Kode Negara, tekan ENTER. Kota Tujuan/Negara Tujuan akan terisi secara otomatis pada kolom Data Penerima.

12) Pilih Nama Produk, tekan ENTER

13) Jika Kiriman EMS DOKUMEN, EMS NON DOKUMEN dan PAKET LN, setelah mengisi berat barang diminta untuk mengisi No. Barcode EMS. Informasi pengisian barcode EMS dapat dilihat pada Gambar 9.

14) Klik OK, maka di layar akan tampil seperti pada Gambar 10.

15) Masukan Berat Aktual, tekan ENTER

16) Jika Berat Barang Lebih dari 2000 gr, maka harus mengisi Volume Metrik. Informasi pengisian Volume Metrik dapat dilihat pada Gambar 11.

17) Klik OK, kemudian isi seperti pada Gambar 12.

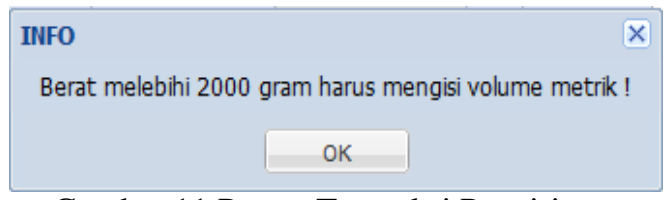

Gambar 11 Proses Transaksi Pengiriman

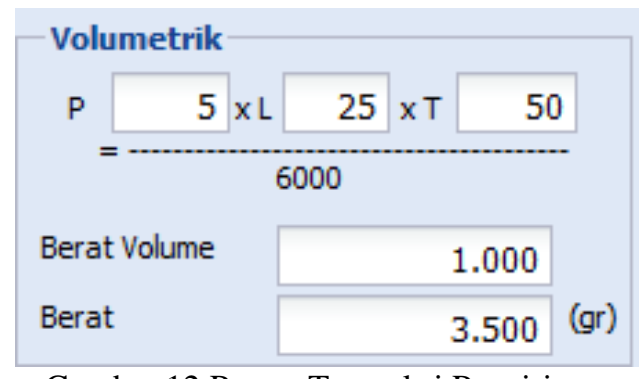

Gambar 12 Proses Transaksi Pengiriman

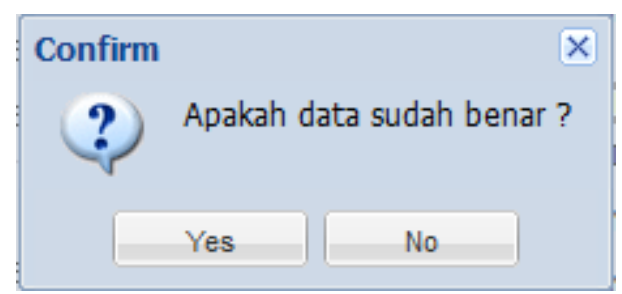

Gambar 13 Proses Transaksi Pengiriman

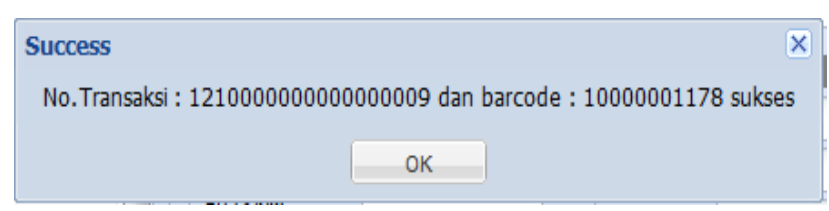

Gambar 14 Proses Transaksi Pengiriman

18) Kemudian tekan ENTER, maka akan muncul secara otomatis Berat Volume

19) Masukan Nilai Barang (Bila Ada), tekan ENTER dan otomatis keluar Bea yang harus dibayarkan

20) Masukan ID Penerima, bila ada akan muncul data pelanggan secara otomatis)

21) Masukan Nama Perusahan (Jika tidak ada, cukup dilewati saja)

22) Masukan Nama Penerima 


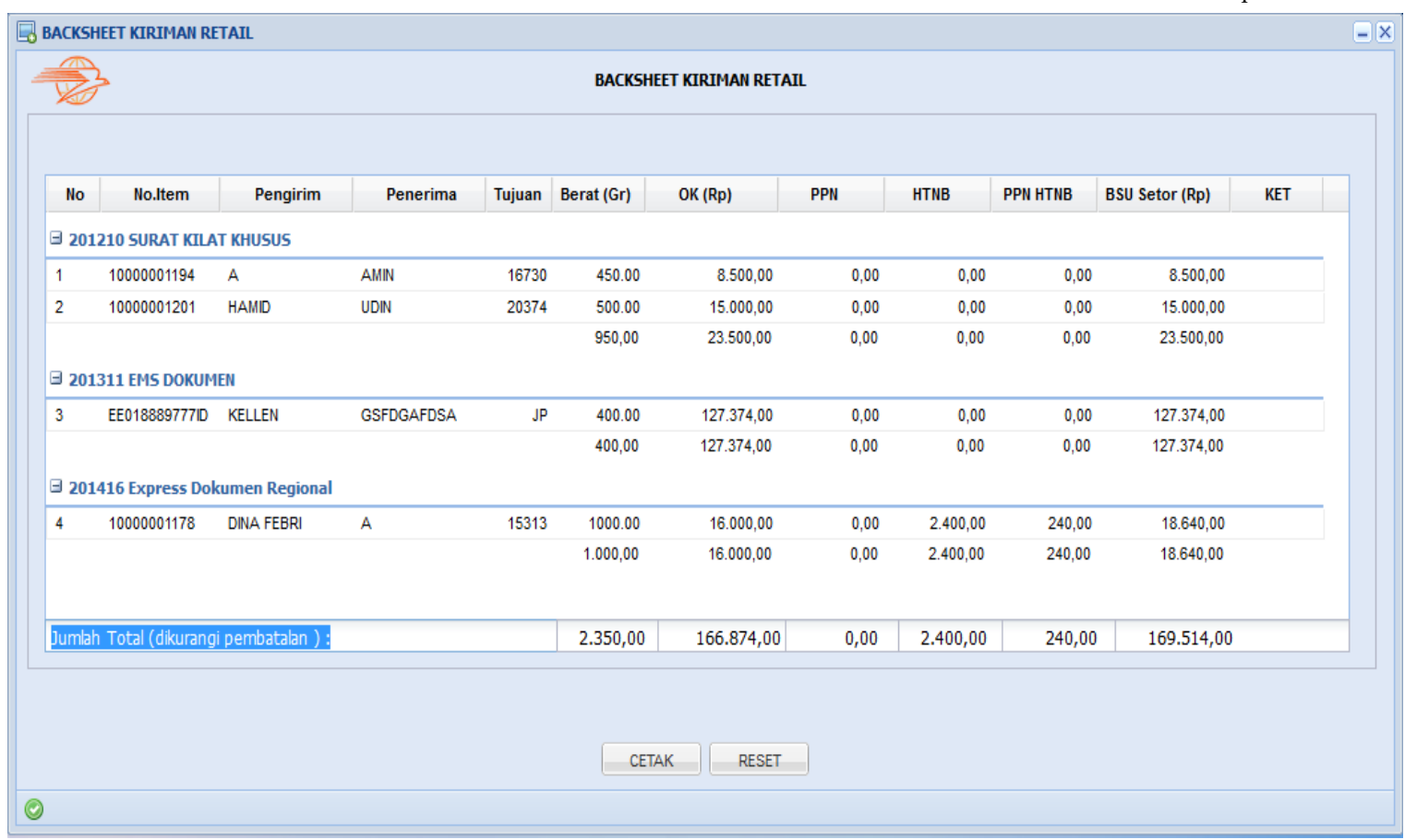

Gambar 15 Proses Pembuatan Backsheet

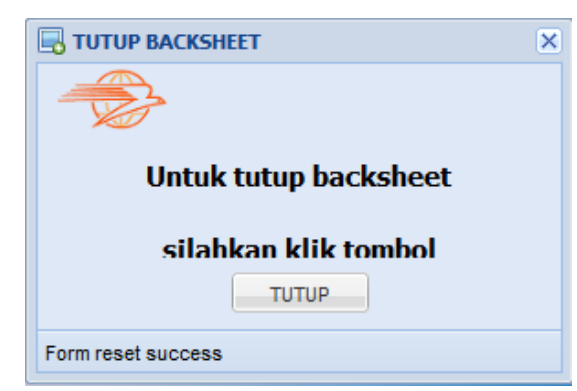

Gambar 16 Proses Tutup Backsheet

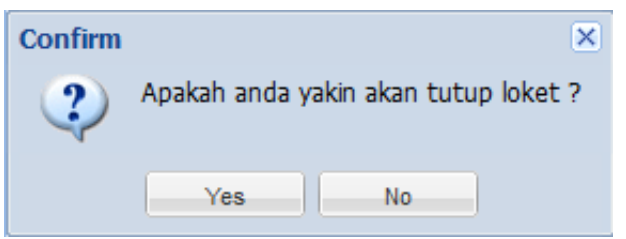

Gambar 17 Proses Tutup Backsheet

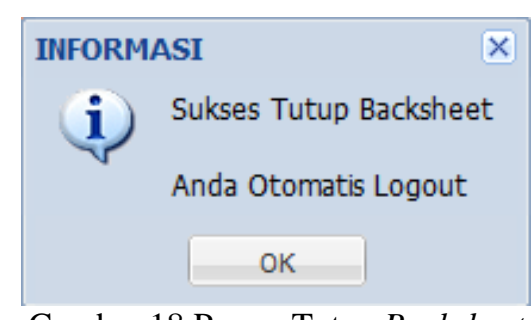

Gambar 18 Proses Tutup Backsheet

23) Masukan Alamat Penerima

24) Masukan No. HP Penerima

25) Masukan E-mail Penerima (Bila Ada)

26) Kota dan Kodepos otomatis telah terisi

27) Masukan Propinsi

28) Negara otomatis telah terisi

29) Masukan ID Pengirim (bila ada akan muncul data pelanggan secara otomatis)

30 | Register: Jurnal Ilmiah Teknologi Sistem Informasi, Januari 2016, Volume 2, Nomor 1

http://www.journal.unipdu.ac.id/index.php/register/article/view/442 
30) Masukan Nama Perusahan (Jika tidak ada, cukup dilewati saja)

31) Masukan Nama Pengirim

32) Masukan Alamat Pengirim

33) Masukan No HP Pengirim

34) Masukan E-mail Pengirim (Bila Ada)

35) Kota dan Kodepos otomatis telah terisi

36) Masukan Propinsi

37) Negara otomatis telah terisi

38) Klik Proses, maka akan muncul pesan konfirmasi seperti pada Gambar 13.

39) Jika data yakin sudah benar, klik Yes maka akan muncul seperti pada Gambar 14.

40) Klik OK, maka otomatis akan dicetak ke printer bentuk resi yang diinginkan

41) Jika Petugas Loket telah selesai melakukan transaksi pada hari ini, tugas selanjutnya Petugas diharuskan untuk mencetak backsheet transaksi pengiriman surat dan barang hari ini.

42) Petugas Loket memilih menu Start-All Programs - Kiriman Pos-Backsheet Kiriman Pos. Proses Pembuatan Backsheet dapat dilihat pada Gambar 15.

43) Klik Cetak, untuk mencetak ke printer.

44) Setelah selesai transaksi dan yakin transaksi hari ini sudah benar, Petugas Loket wajib melakukan Tutup Backsheet.

45) Klik Tutup Backsheet, di layar muncul seperti pada Gambar 16.

46) Klik Tutup, maka di layar muncul seperti pada Gambar 17.

47) Klik Yes, maka di layar muncul seperti pada Gambar 18.

48) Klik OK.

\subsection{Hasil Analisis Aplikasi IPOS Menggunakan Metode PIECES}

Kantor Pos Jombang menerapkan sebuah aplikasi yang digunakan untuk proses transaksi pengiriman surat atau barang, yaitu Aplikasi IPOS. Menerapkan sebuah aplikasi, perlu dilakukan analisis untuk mencari tahu apakah aplikasi yang diterapkan tersebut layak ataukah tidak. Analisis yang dilakukan oleh penulis menggunakan metode Analisis PIECES (Performance, Information, Economic, Control, Efficiency, Service). Analisis PIECES yaitu analisis yang mencermati kinerja, informasi, ekonomi, keamanan, efisiensi, dan layanan. Berikut hasil Analisis PIECES terhadap kelayakan Aplikasi IPOS untuk proses transaksi pengiriman surat atau barang:

a) Performance

Proses transaksi pengiriman surat dan barang menggunakan Aplikasi IPOS memakan waktu kurang lebih lima menit. Proses ini dinilai lebih baik dibandingkan menggunakan sistem manual yang memakan waktu kurang lebih sepuluh menit. Kelebihan yang mendukung performance Aplikasi IPOS antara lain:

1) ID Pelanggan, apabila pelanggan telah memiliki ID Pelanggan maka data pengirim terisi secara otomatis.

2) Kode POS, apabila Petugas Loket memasukkan kode POS maka kota/negara tujuan akan terisi secara otomatis.

3) Volume Metrik, apabila Petugas Loket memasukkan panjang, lebar, dan tinggi barang maka volume metrik akan terisi secara otomatis.

4) Bea Pengiriman, apabila barang memiliki nilai barang (jika diuangkan) maka bea pengiriman akan terisi secara otomatis.

5) Loket Korporat by File, dalam satu kali proses transaksi pengiriman surat dan barang menggunakan Loket Korporat by File mampu memproses \pm 3000 transaksi dalam sekali input file.

6) Backsheet Kiriman Pos, mudahnya membuat laporan transaksi harian (Backsheet Kiriman Pos), Petugas Loket tidak perlu memasukkan data transaksi harian satu per satu karena data transaksi harian telah tercatat secara otomatis melalui Aplikasi IPOS.

b) Information

Informasi yang disajikan oleh aplikasi IPOS adalah informasi yang akurat, ter-update, dan relevan. Berikut adalah penjelasan dari informasi yang dihasilkan oleh IPOS:

1) Akurat, Jarang terjadi kekeliruan atau selisih antara laporan transaksi harian (Backsheet Kiriman Pos) dengan uang yang didapat. 
2) Update to date, Pembaruan data kurs rupiah dilakukan setiap waktu secara otomatis.

3) Relevan, Pemberian laporan transaksi harian oleh Petugas Loket ke Manajer Pelayanan dapat dilakukan tepat waktu. Setelah Petugas Loket melakukan Petugas hanya perlu mencetak backsheet kiriman pos tanpa input data transaksi satu per satu. Setelah mencetak backsheet Petugas Loket dapat langsung menyerahkannya kepada Manajer Pelayanan.

c) Economic

Aplikasi IPOS berbasis web dapat menghemat biaya pembaruan sistem karena dapat dilakukan secara serentak oleh server pusat. Pembaruan sistem dengan cara ini dinilai lebih hemat dibandingkan Aplikasi IPOS berbasis desktop. Pembaruan sistem berbasis desktop harus dilakukan dengan cara install ulang aplikasi secara manual untuk seluruh Kantor Pos. Pembaruan sistem dengan cara ini akan memakan banyak waktu, tenaga, dan biaya.

d) Control

Keamanan sistem yang digunakan adalah dengan menggunakan jaringan intranet. Untuk akses aplikasi, digunakan sistem login dengan username dan password yang berbeda untuk masingmasing Petugas dan sistem logout otomatis jika aplikasi tidak digunakan selama sepuluh menit.

e) Efficiency

1) Melalui menu Loket Korporat by File, dalam satu kali proses transaksi pengiriman surat dan barang mampu memproses \pm 3000 transaksi dalam sekali input file.

2) Aplikasi IPOS memiliki kendala dengan bandwidth yang rendah sehingga proses loading transaksi terkadang memakan waktu yang lama.

f) Services

Dengan memanfaatkan Aplikasi IPOS, proses transaksi dapat dilakukan dengan cepat dan mudah. Proses transaksi yang cepat dapat memberikan layanan yang cepat kepada pelanggan sehingga pelanggan tidak perlu antri lama.

\subsection{Rekomendasi}

Tujuan utama dari analisis Aplikasi IPOS di Kantor Pos Jombang adalah memberikan rekomendasi untuk perbaikan aplikasi di masa mendatang. Berdasarkan hasil analisis, rekomendasi yang dapat dijadikan acuan dalam perbaikan Aplikasi IPOS di masa mendatang adalah sebaiknya Kantor Pos Jombang menambah ukuran bandwidth agar proses loading lebih cepat, sehingga dapat meningkatkan kualitas pelayanan dalam segi waktu.

\section{Kesimpulan}

Aplikasi IPOS diterapkan untuk proses transaksi pengiriman surat dan barang pada Loket Retail di PT. Pos Indonesia (Persero) KPRK Jombang. Berdasarkan analisis PIECES yang dilakukan dapat disimpulkan bahwa penggunaan Aplikasi IPOS dalam proses transaksi pengiriman surat dan barang di PT. Pos Indonesia (Persero) KPRK Jombang dikatakan layak. Aplikasi IPOS dapat mempercepat dan mempermudah proses transaksi pengiriman, serta dapat memberikan informasi yang akurat, tepat waktu, dan relevan.

Berdasarkan Metode PIECES yang telah dilakukan, pada aspek Performance, proses transaksi pengiriman menggunakan Aplikasi IPOS hanya membutuhkan waktu kurang lebih lima menit, lebih baik dibandingkan penggunaan sistem manual yang memakan waktu kurang lebih sepuluh menit. Pada aspek Information, Aplikasi IPOS dapat memberikan informasi yang akurat, tepat waktu, dan relevan. Sedangkan pada aspek Economic, Aplikasi IPOS dapat meminimalisir biaya untuk pembaruan sistem dibandingkan install ulang aplikasi secara manual. Kemudian untuk aspek Control, Aplikasi IPOS dapat digunakan dengan aman dengan memanfaatkan jaringan intranet. Pada aspek Efficiency, Aplikasi IPOS dapat melakukan transaksi dengan cepat. Dan pada aspek yang terakhir yaitu Services, Aplikasi IPOS dapat memberikan kemudahan transaksi sehingga Kantor Pos Jombang dapat memberikan pelayanan terbaik bagi konsumen.

\section{Referensi}

Al Fatta, H. (2007). Analisis dan Perancangan Sistem Informasi untuk Keunggulan Perusahaan dan Organisasi Modern. Yogyakarta: Andi.

Djahir, Y., Pratita, D. (2015). Bahan Ajar Sistem Informasi Manajemen. Jakarta: DEEPUBLISH. 
Gaol, Chr. Jimmy L. (2008). Sistem Informasi Manajemen. Yogyakarta: Grasindo.

Kadir, A. (2014). Pengenalan Sistem Informasi. Yogyakarta: Andi.

Tullah, R., Hanafri, M. (2014). Evaluasi Penerapan Sistem Informasi pada Politeknik LP3I Jakarta dengan Metode PIECES. Jurnal SISFOTEK GLOBAL, 4(1), 1-7.

Nuryati., Widayanti, N. (2015). Evaluasi Implementasi Sistem Electronic Health Record (EHR) di Rumah Sakit Akademik Universitas Gadjah Mada Berdasarkan Metode PIECES. Jurnal Manajemen Informasi Kesehatan Indonesia, 3(1), 19-28. 